\title{
International Environmental Law (2018)
}

\author{
Marlies Hesselman*
}

\section{Introduction}

The field of international environmental law is highly relevant to the prevention of, preparedness for, response to and recovery from disasters. Most obviously, environmental law is important because poorly managed environmentally hazardous situations can directly cause or contribute to the occurrence of both slow-onset and sudden-onset disasters, while various disaster events, such as oil spills, volcanic eruptions, forest fires or climate disasters can also lead to widespread, irreparable environmental damage, including to vulnerable habitats and eco-systems as protected under international treaties. ${ }^{1}$ In addition, as discussed below, it is increasingly recognised that environmental treaties may be instrumental to adequately managing disaster risk and keeping human settlements safe, in the sense that they protect essential eco-system services of nature.

In fact, definitions of "disasters", including in the ILC's Draft Articles on the Protection of Persons in Event of Disasters, often refer to 'environmental' aspects of disasters, both in terms of 'natural' hazards or in terms of environmental damage sustained. ${ }^{2}$

Before assessing some key developments during 2018, it is worth to briefly note that "international environmental law" tends to suffer from some similar problems as "international disaster law", especially in that both fields lack a clear "core" treaty which anchors the key legal principles. Instead, relevant provisions of international environmental law are contained in loosely interrelated regional and international multi-lateral environmental agreements (MEAs),

* Lecturer in International Law, University of Groningen.

1 See e.g. Jacqueline Peel, 'International Environmental Law and Climate Disasters' in Rosemary Lyster and Robert Verchick (eds), Research Handbook on Climate Disaster Law: Barrit ers and Opportunities (Edward Elgar 2018); Jacqueline Peel and David Fisher (eds), The Role of International Environmental Law in Disaster Risk Reduction (Martinus Nijhoff 2016); Tim Stephens, 'Disasters, International Environmental Law and the Anthropocene' in Susan Breau and Katja Samuel (eds), Research Handbook on Disasters and International Law (Edward Elgar 2016).

2 ILC, 'Report of the International Law Commission - Sixty-eighth session' (2 May-10 June and 4 July-12 August 2016) UN Doc A/71/10: “disaster" means a calamitous event or series of events resulting in [...] large-scale material or environmental damage, thereby seriously disrupting the functioning of society'. 
or in "environmental-related" treaties, such as the UN Convention on the Law of the Sea, Humanitarian Law treaties, or World Trade treaties. It is a striking coincidence then, that in 2018 the UN General Assembly (UNGA) considered the adoption of "core treaties" for both international environmental law, in terms of a Global Pact for the Environment, and international disaster law, based on the ILC Draft Articles (see also the thematic focus of this Yearbook). ${ }^{3}$

This short contribution will largely review relevant developments as related to the Global Pact for the Environment, as it may serve both as an inspiration for and apply to the field of international disaster law, and some interesting developments under selected MEAs that had Conferences of Parties (cops) in 2018. A particular worthwhile development constitutes the adoption of the Regional Agreement on Access to Information, Public Participation in Decision-Making and Access to Justice by the UN Economic Commission for LatinAmerica and the Caribbean (ECLAC). In so far that aspects of hazardous waste management, climate change, marine disasters, or 'human rights and the environment' are covered by other sections in this issue, they are not repeated here. $^{4}$

\section{UNGA Moves towards a Global Pact on the Environment}

On 10 May 2018, UngA Resolution 72/277 on 'Towards a Global Pact for the Environment' endorsed an initiative commenced by a group of 100 legal experts throughout 2017, and ultimately spearheaded by France. Resolution $72 / 227$ calls both for the assessment of 'possible gaps in international environmental law and environment-related instruments', as well as exploration of 'the scope, parameters and feasibility' of an international instrument to fill such gaps. ${ }^{5}$

3 See, for reflections: Special Issue: The Global Pact for the Environment and Gaps in International Environmental Law (2019) 28 Reciel 1; Giulio Bartolini, "The Draft Articles on "The Protection of Persons in the Event of Disasters": Towards a Flagship Treaty?' (EJIL:Talk!, 2 December 2016) <https://www.ejiltalk.org/the-draft-articles-on-the-protection-of-persons -in-the-event-of-disasters-towards-a-flagship-treaty> last accessed (as any subsequent URL) 30 June 2019.

4 See e.g. sections on human rights, climate change or law of the sea, in this issue.

5 UNGa Res 72/227 (10 May 2018) UN Doc A/RES/72/227; Le Club des Juristes', Draft Project: Global Pact on the Environment' (Sorbonne Paris, 24 June 2017), available at <https://www .iucn.org/sites/dev/files/content/documents/draft-project-of-the-global-pact-for-the-envi ronment.pdf $>$. For background information see $<$ https://globalpactenvironment.org/en/the -pact/where-are-we-now/>. 
In December 2018, UN Secretary-General Guterres fulfilled the first aspect of the resolution by publishing his report entitled 'Gaps in international environmental law and environment-related instruments: towards a global pact for the environment'. ${ }^{6}$ Guterres found that effective implementation of international environmental law could be strengthened by a 'single overarching normative framework that sets out what might be characterized as the rules and principles of general application in international environmental law', in the sense that such principles 'may help unify the current, sectoral approach to international environmental law and help fill the gaps in the rules laid out in treaties'. Additionally, while certain international environmental law principles received recognition in issue-specific MEAs and/or have been affirmed by international courts and tribunals, other principles 'enjoy neither clarity nor judicial consensus [...] nor recognition in binding legal instruments'; this impacts their 'predictability and implementation of sectoral environment regimes'. Guterres also laments the fragmented and incoherent nature of MEAs and related instruments, and notes that a single instrument might promote 'policy coherence, mutual supportiveness and synergies in implementation' of different instruments. Resolution 72/227 also established an ad hoc open-ended working group to consider the report and to discuss possible options to respond, including the new instrument, open to all UNGA Members and members of specialised agencies, and with participation of civil society. The proceedings of this working-group throughout 2019 can be easily followed via globalpact.informea.org or sdg.iisd.org, and may be revisited in the following YIDL.

In any case, the Pact itself is an inspiration for future similar efforts in relation to international disaster law, and may endorse environmental principles directly relevant to disasters. Both Guterres and the Group of Experts in this respect point to obligations of international cooperation in relation to emergencies in particular, especially duties to notify and assist. According to Guterres such obligations serve to prevent dangers posed by certain dangerous activities/substances and 'natural' disasters. ${ }^{7}$ He further considers that the obligation to notify in case of emergencies is already a part of customary international law', but that the 'duty of assistance in such events has received only limited recognition' apart from recognition in specific 'foundational

6 UNGA, 'Report of the Secretary-General: Gaps in International Environmental Law and Environment-Related Instruments: Towards a Global Pact for the Environment' (30 November 2018) UN Doc A/73/419.

7 Ibid., para. 17. 
instruments of international environmental law' and article 7 of the aforementioned ILC Draft Articles. ${ }^{8}$

Arguably, other environmental law principles will apply to disaster risk management activities as well, including principles of Environmental Impact Assessment, the continuous monitoring of disaster risks and early warning activity, access to information, or the conservation/sound management of important natural areas for purposes of DRR or climate change mitigation (see below and e.g. Principle 16 on 'resilience' in the Draft Pact). ${ }^{9}$

\section{3}

\section{Disaster Law and Selected Multi-Lateral Environmental Agreements}

While many classic MEAs may be immediately relevant to disaster prevention, preparedness, response and recovery, not all of them annually have cops or MOPs, nor do they necessarily discuss matters of disaster or emergency management in any given COP. ${ }^{10}$ Indeed the joint cops of the Basel Convention, the Stockholm Convention and the Rotterdam Convention for example took place in 2017 and 2019, and appear not to have focussed on specific disaster issues. ${ }^{11}$

$8 \quad$ Ibid.

9 Le Club des Juristes (n. 5). Draft Principle 16 on 'resilience' reads: '[t] he Parties shall take necessary measures to maintain and restore the diversity and capacity of ecosystems and human communities to withstand environmental disruptions and degradation and to recover and adapt'.

10 Besides a range of treaties that relate specifically to marine pollution from ships, industrial accidents or hazardous substances/waste management such as the MARPOL Convention, Helsinki Convention on Transboundary Effects of Industrial Accidents, Vienna Conventions on nuclear activities, Rotterdam Convention on Prior Informed Consent for Certain Hazardous Chemicals and Pesticides in International Trade, London Convention on Prevention of Pollution of the Sea by Oil, or Basel Convention on Transboundary Movements of Hazardous Wastes and their Disposal, relevant MEAs would include the 1972 Unesco World Heritage Convention (WHC), the 1971 Ramsar Convention on Wetlands of International Importance, the 1992 UN Convention on Biodiversity (CBD), the 1994 Convention on Combatting of Desertification (CCD), the 1992 UNECE Convention on the Protection and Use of Transboundary Watercourses and International Lakes (Water Convention) or 1991 Espoo Convention on Environmental Impact Assessment in a Transboundary Context. See Flavia Zorzi Giustianini, 'Cultural Heritage', in this volume.

11 See Anastasia Telesetsky, 'Law of the Sea', in this issue noting the focus on marine plastic pollution as a 'non-traditional disaster', especially under the Basel Convention presently. 

Addressing Sand and Dust Storms as Disaster Risk

A particular concern raised by Parties to the 1992 Convention on Combatting Desertification (CCD) in recent years is the disastrous impact of sand and dust storms (SDS) on human health, infrastructure, agriculture, communication and other areas of life. In 2018, the CCD Secretariat developed a science-based communication tentatively titled 'Sand and Dust Storms Compendium: Information and Guidance on Assessing and Addressing the Risks Posed by Sand and Dust Storm' to be discussed at COP 14 in 2019 as a follow-up to the CCD's 'Policy Advocacy Framework to Combat Sand and Dust Storms' adopted at COP 13 in 2017. ${ }^{12}$ This compendium aids CCD parties in defining the scope of SDS impacts and the development plans to address them. ${ }^{13}$ It provides guidance on 'approaches and methodologies of data collection, assessment, monitoring, forecasting, early warning, impact mitigation and preparedness, source mapping and anthropogenic source mitigation', and specifically stresses the need to understand SDS as a proper 'disaster risk' per the UN Sendai Framework.

As highlighted by the 2017 Policy Framework, there is currently insufficient awareness about SDS in various parts of the world, despite the fact that such storms are increasing in frequency and intensity, and can be life threatening for individuals with compromised health; they constitute a serious concern which requires a proper 'institutional, technical and scientific response'. Supposedly some 151 CCD Parties are directly affected by SDS, while 45 Parties are source areas. ${ }^{14}$ At CCD COP 14 there is thus an opportunity to further consolidate the $\mathrm{CCD}$ as a platform to address this specific disaster risk.

\subsection{Biodiversity Convention and Ramsar Wetlands Conventions: Protecting and Promoting Valuable Eco-Systems for Eco-DRR}

Both СвD and the Ramsar Convention COPs have a long history of referring to climate change, disasters and risk reduction in their decision-making on the implementation of these treaties.

In 2018 specifically, CBD COP 14 adopted a set of 'Voluntary guidelines for the design and effective implementation of ecosystem-based approaches

\footnotetext{
12 CCD, 'Decision 31/COP.13: Policy Advocacy Framework to Combat Sand and Dust Storms' (15 September 2017) CCD/COP(13)/21/Add.1.

13 CCD, 'Follow-up on Policy Frameworks and Thematic Issues: Sand and Dust Storms: Note by the Secretariat' (advance unedited version for COP 14 in India, New Delhi, 2-13 September 2019) available at <https://www.unccd.int/sites/default/files/sessions/documents/ 2019-06/COP142017SDS_draft_revoradvance.pdf>.

For more information, see <https://www.unccd.int/actions/sand-and-dust-storms $>$.
} 
to climate change adaptation and disaster risk reduction' that promote 'ecosystem-based disaster risk reduction' (eco-DRR) as the 'holistic, sustainable management, conservation and restoration of ecosystems to reduce disaster risk'. The document also proposes that the management of relevant ecosystems may be usefully included and thus monitored as part of nationally determined contributions (NDCs) and national adaptation plans under the UNFCCC/Paris Agreement. ${ }^{15}$

Ramsar COPs have similarly addressed the unique and critical role of wetlands as valuable eco-systems in the sphere of climate change mitigation and disaster risk reduction, and the importance of securing their conservation and wise use for purposes under the auspices of the Convention. In fact even the International Court of Justice (ICJ) underscored in 2018 - in its first ever environmental damages award, which involved complaints about the destruction of Ramsar wetlands and impaired natural hazard mitigation capacity - that wetlands 'are among the most diverse and productive ecosystems in the world' and 'perform many vital functions, including supporting rich biological diversity [and] regulating water regimes'.16 Ramsar Convention COP 13 in October 2018 adopted a range of resolutions on the matter, including one encouraging States to develop or improve legislation on restoration and rewetting of degraded peatlands, conserve existing peatlands, and restore degraded peatlands in their territory 'as one means to contribute to climate-change mitigation, adaptation, biodiversity conservation, and disaster risk reduction', especially in combination with more 'hard' engineering DRR options, such as dykes or dams. ${ }^{17}$ COP 13 Resolution XIII.12 further endorsed a significant decision to add 'global climate change regulation' to the existing criteria for identification

15 Voluntary Guidelines adopted by and contained in СBD, 'Decision 14/5: Biodiversity and climate change' (Sharm El-Sheikh, Egypt, 17-29 November 2018) CBD/COP/DEC/14/5, para. 5, p. 7; see further CBD, 'Decision XIII/4. Biodiversity and Climate Change' (Cancun, Mexico, 10 December 2016) CBD/COP/DEC/XIII/4, para. 10; Secretariat of the CBD, 'СвD Technical Series No. 85: Synthesis Report on Experiences with Ecosystem-Based Approaches to Climate Change Adaptation and Disaster Risk Reduction' (October 2016), available at <https://www.cbd.int/doc/publications/cbd-ts-85-en.pdf>.

16 ICJ, Certain Activities Carried Out by Nicaragua in the Border Area (Costa Rica v Nicaragua) (Compensation) [2018] General List No. 150, paras. 55, 64-67, 74-75, 80, 89. The ICJ awarded compensation to Costa Rica for the loss of carbon sequestration services from the Ramsar wetlands, but did not find evidence that capacity for natural hazard mitigation was lost in this instance.

17 Ramsar Convention COP 13, 'Resolution XIII.13 Restoration of Degraded Peatlands to Mitigate and Adapt to Climate Change and Enhance Biodiversity and Disaster Risk Reduction' (21-29 October 2018), paras. 22-24. 
of protected peatlands under art. 2 of the Convention..$^{18}$ Finally, the Convention's Secretariat produced a further policy brief to promote States Parties' 'restoration' of wetlands in the widest sense of the Convention's term, stressing the unique and critical contribution of wetlands to DRR, and following-up on an earlier brief on wetland restoration for DRR specifically. ${ }^{19}$ While the Ramsar Convention includes few hard binding legal obligations, the Ramsar regime clearly provides a useful entry point for guidance, monitoring and international cooperation on the conservation and integration of critical ecosystems in DRR activity; incidentally, synergies with other MEAs, such as the CBD or UNFCCC are regularly pursued.

\subsection{UNECE Water Convention: Guidelines for Water-Related Disasters and Transboundary Cooperation}

In the context of water-related disasters, the UN Economic Commission for Europe (UNECE) adopted its 'Words into Action Guidelines: Implementation Guide for Addressing Water-Related Disasters and Transboundary Cooperation'. The aim of these guidelines is to strengthen the capacity of Member States to implement the Sendai Framework on Disaster Risk Reduction and the 1992 UNECE Convention on the Protection and Use of Transboundary Watercourses and International Lakes (Water Convention). The Guidelines also clarify that the 'guide is not legally binding and does not preclude the legal obligations arising from the Convention.' 20

A first important observation of the Guide, applying to many older treaty instruments, is that the Water Convention was drafted at a time when DRR concepts and principles were still very much under development, and therefore perhaps not well articulated in treaty texts; yet, the Convention is clearly relevant to DRR in various ways, including through provisions on emergencies and monitoring of risks. The Guide actually provides an overview of how

18 Ramsar Convention COP 13, 'Resolution XIII.12 Guidance on identifying peatlands as Wetlands of International Importance (Ramsar Sites) for global climate change regulation as an additional argument to existing Ramsar criteria' (21-29 October 2018).

19 Ramsar Convention Secretariat, 'Ramsar Briefing Note No. 10: Wetland Restoration for Climate Change Resilience' (2018); R. Kumar et al, 'Wetlands for Disaster Risk Reduction: Effective Choices for Resilient Communities - Ramsar Policy Brief No. 1' (Ramsar Convention Secretariat 2017), available at <https://www.ramsar.org/sites/default/files/docu ments/library/rpb_wetlands_and_drr_e.pdf>.

20 UN, 'Words into Action Guidelines: Implementation Guide for Addressing Water-Related Disasters and Transboundary Cooperation' (October 2018) $3^{-4}$, available at $<$ https://www .unece.org/index.php?id=50093 $>$; see for relevant articles, UnECE Convention on the Protection and Use of Transboundary Watercourses and International Lakes, 17 March 1992, arts. 3, 9, 13-14. 
various MEAs apply to water management and DRR, and points out the OECD Principles on Water Governance when noting that well-integrated, multi-level, multi-stakeholder transboundary water management is highly challenging and requires extensive international cooperation. In order to determine where DRR can be mainstreamed in law and policy arrangements, the enabling environment of existing policy, legal and institutional frameworks have to be carefully assessed, which in a transboundary context would at least include law and policy arrangements at river basin level (including basin-wide sectoral strategies and/or overall basin plans), national or transboundary Flood Risk Management and Drought Management Plans, and the existence of EIAs and SEAs per the Espoo Convention. ${ }^{21}$ The Guide also recommends States to establish 'transboundary legal frameworks' to ensure sustained technical cooperation, while encouraging to keep formal arrangements flexible and crosssectoral in nature. ${ }^{22}$ In this context, Parties are invited to use the UNECE Model Provisions on Transboundary Flood Management (2006) to develop suitable bi- or multilateral agreements. ${ }^{23}$

\section{Escazú Regional Agreement on Access to Information, Public Participation and Justice in Environmental Matters}

Finally, on 4 March 2018 the 'Regional Agreement on Access to Information, Public Participation and Justice in Environmental Matters in Latin America and the Caribbean' was adopted in Escazú, Costa Rica under auspices of the UN Economic Commission for Latin-America and the Caribbean (UNECLAC). The 'Escazú Agreement' is inspired by the UnEce Aarhus Convention, but in some respects also seems to strengthen protection in comparison to the Aarhus Convention.

For example, while it similarly protects the public's right to freely request access to environmental information possessed by public authorities, without stating a specific interest (article 5(2)), the Agreement is more explicit in its endorsement of the right to live in a healthy environment, and also provides in a fairly detailed manner that parties:

\footnotetext{
21 Ibid., 21, 25, 38.

22 Ibid., 21, 25.

23 UNeCE, 'Model Provisions on Transboundary Flood Management' (2006) published in: UNECE Convention on the Protection and Use of Transboundary Watercourses and International Lakes, 'Transboundary Flood Risk Management: Experiences from the UNECE Region' (UNECE 2009).
} 
shall guarantee, to the extent possible within available resources, that the competent authorities generate, collect, publicize and disseminate environmental information relevant to their functions in a systematic, proactive, timely, regular, accessible and comprehensible manner, and periodically update this information and encourage the disaggregation and decentralization of environmental information at the subnational and local levels. ${ }^{24}$

This provision is clearly relevant to disaster risk management authorities, as is article 6(5) which provides that in cases of 'imminent threats to public health or the environment', the Parties have to guarantee that the relevant competent authority 'immediately disclose and disseminate through the most effective means all pertinent information in its possession that could help the public take measures to prevent or limit potential damage'; moreover each Party has to 'develop and implement an early warning system using available mechanisms' (article 6(5)).

It remains to be seen how the implementation of this exciting new instrument will develop after its entry into force, and if any interesting synergies with either the Aarhus Convention, or the Inter-American Commission on $\mathrm{Hu}-$ man Rights' Advisory Opinion of Human Rights and the Environment of 2018, might ensue. ${ }^{25}$ Similarly, it is an interesting question whether the 'consultative, transparent, non-adversarial, non-judicial and non-punitive' implementation and compliance committee envisioned by article 18 of the Agreement will be tasked with similar functions as the Aarhus Compliance Committee - including the competence to hear communications. In any case, reviews by the new body will be recommendatory in nature, even if the Agreement itself constitutes a binding treaty. ${ }^{26}$

24 Escazú Agreement, art. 6(2), emphasis added. See for recent discussion and comparison of the Agreement in relation to Aarhus and disaster risk information: Marlies Hesselman, 'Access to Disaster Risk Information, Early Warning and Education: Implementing the Sendai Framework through Human Rights Law' in Katja Samuel, Marie Aronsson-Storrier, and Kirsten Nakjavani Bookmiller (eds), The Cambridge Handbook of Disaster Risk Reduction and International Law (CUP 2019) 188-216.

25 See practice section by Marlies Hesselman, 'Human Rights Law', in this issue.

26 See further Ezcazú Agreement, art. 18. 